\title{
MODEL KAUSALITAS ANTARA TINGKAT INFLASI, SUKU BUNGA DAN NILAI KURS DOLLAR AS TERHADAP INDEKS HARGA SAHAM GABUNGAN PADA BURSA EFEK INDONESIA
}

\author{
Aminar Sutra Dewi ${ }^{1}$, Vira Yulia Viska ${ }^{2}$ \\ Sekolah Tinggi Ilmu Ekonomi “KBP” Padang \\ E-mail : aminarsd@gmail.com; Virayuliaviska26071995@gmail.com
}

\begin{abstract}
This research conducted to find out either simultaneously or partially the influence of the inflation rate, the interest rate and the exchange rates of the US Dollar on composite stock price indeks in Indonesia Stock Exchange. This type or research is quantitative research. Data analysis technique used is multiple linear regression using the program eviews. The results of this study indicite that: 1) inflation rate variable has negative effect that is not significant to composite stock price indeks, 2) the interest rate variable has negative effect significantly to composite stock price indeks, 3) the exchange rates of the US Dollar variable effect significantly positive to the exchange rates of the US Dollar. Determination of coefficient test result shows that the three variable used may explain the variable composite stock price indeks $40,86 \%$ while the remaining $59,14 \%$ influenced by other variables outside this research model.
\end{abstract}

Keywords: Composite Stock Price Indeks, Inflation Rate, Interest Rete and Exchange Rates Of The US Dollar

\section{PENDAHULUAN}

Pasar modal merupakan salah satu instrumen ekonomi dewasa ini yang mengalami perkembangan sangat pesat. Pasar modal merupakan indikator kemajuan perekonomian suatu negara serta menunjang ekonomi negara yang bersangkutan (Robert, 1997). Pasar modal memilki peran penting bagi perekonomian suatu negara. Dengan adanya pasar modal (capital market), investor yang sebagai pihak yang memiliki kelebihan dana dapat menginvestasikan dananya pada berbagai sekuritas dengan harapan memperoleh imbalan (return). Sedangkan bagi perusahaan sebagai pihak yang memerlukan dana dapat memanfaatkan dana tersebut untuk mengembangkan proyek-proyeknya. Dengan alternatif pendanaan dari pasar modal, perusahaan dapat beroperasi dan mengembangkan bisnisnya dan pemerintah dapat membiayai berbagai kegitannya sehingga meningkatkan kegiatan perekonomian negara. (Tandelilin, 2010)

Kegiatan investasi adalah kegiatan menanamkan atas sejumlah dana baik langsung maupun tidak langsung dengan tujuan memperoleh keuntungan dimasa depan. Salah satu kegiatan yang dapat dipilih oleh investor adalah berinvestasi di pasar modal. Di indonesia, investor yang berminat untuk berinvestasi di pasar modal dapat berinvestasi di Bursa Efek Indonesia (BEI).

Bursa Efek Indonesia mempunyai satu indikator indeks yang sering diperhatikan investor ketika berinvestasi di Bursa Efek Indonesia adalah Indeks Harga Saham Gabungan.Indeks Harga Saham Gabungan dapat menjadi leading indicator economic pada suatu negara. Pergerakan pasar yang sedang mengalami peningkatan atau mengalami penurunan dapat dilihat dari nilai-nilai saham yang tercatat dan tercermin melalui pergerakan indeks atau lebih dikenal dengan Indeks Harga Saham Gabungan (IHSG). Indeks 
Harga Saham Gabungan atau Composite Stock Price Indeks (IHSG) merupakan suatu nilai yang digunakan untuk mengukur kinerja kerja saham yang tercatat di suatu bursa efek. IHSG dapat mencerminkan bursa efek, apakah pasar sedang dalam keadaan bullish (harga saham cenderung bergerak naik) atau dalam keadaan bearish (harga saham cenderung bergerak turun).

Di dalam pasar modal terdapat beberapa variabel yang juga ikut serta dalam mempengaruhi Indeks Harga Saham Gabungan (IHSG) antara lain adalah Tingkat Inflasi, Suku Bunga, Nilai Tukar Rupiah pada US Dollar.

Tingginya tingkat inflasi dapat menurunkan daya beli masyarakat dan juga meningkatnya harga faktor produksi. Hal itu biasanya akan berdampak pada anggapan pesimis mengenai prospek perusahaan yang menghasilkan barang atau jasa yang terkena dampak inflasi sehingga dapat mempengaruhi penawaran harga saham perusahaan tersebut dan pada akhirnya berakibat pada pergerakan indeks harga saham di BEI.

Tingkat suku bunga juga merupakan salah satu variabel yang dapat mempengaruhi harga saham.Kenaikan suku bunga yang agresif bisa memperkuat rupiah, tapi Indeks Harga Saham Gabungan (IHSG) akan anjlok karena investor akan memilih menabung di bank. Apabila suku bunga mengalami peningkatan maka harga saham akan mengalami penurunan.

Terdapat alternatif investasi lain yang juga dapat mempengaruhi transaksi saham di bursa efek, yakni investasi pada valuta asing dalam hal ini adalah dollar (USD). Kurs mempengaruhi kompetitif suatu perusahaan karena perubahan kurs diikuti perubahan nilai tukar pendapatan dan biaya operasional perusahaan, sehingga peruahan kurs secara langsung

mempenngaruhi

perubahan harga saham.

Indeks Harga Saham Gabungan mengalami peningkatan yang semakin pesat sejak krisis ekonomi yang melanda Indonesia pada tahun 1998. Hal ini ditunjukkan dari perkembangan nilai IHSG dan nilai transaksi. Nilai IHSG mengalami peningkatan hingga 470 persen dari tahun 2003 sampai akhir tahun 2007.Namun krisis ekonomi global mulai awal 2008 bedampak pada pasar modal indonesia. Tercermin dari jatuhnya nilai IHSG sebesar 61,62 persen dalam kurun waktu yang relatif singkat (satu tahun) dan telah mengakibatkan para investor baik itu dari dalam maupun luar negeri lebih berhati-hati dalam menginvestasikan dananya terutama di pasar modal indonesia. (Hartono,2013).

Fenomena adanya dua krisis dunia yang hampir bersamaan yaitu berkisar pada pertengahan tahun 2015 dimana Yunani dan serta China sama-sama mengalami krisis yang juga sangat berdampak negatif untuk Indonesia, IHSG Fluktuatif bergerak naik dan turun secara tajam merespons perkembangan penanganan krisis Eropa pada tahun 2015 lalu. (Dewantoro,2014). Penurunan Indeks Harga Saham Gabungan pada tahun 2015 bukan hanya disebabkan oleh Yunani dan China tapi terjadi akibat adanya spekualsi mengenai kebijakan yang akan diambil bank sentral AS atau The FED di tahun 2015 yang berkaitan dengan kenaikkan tingkat suku bunga dan menguatanya dollar AS sehingga investor menjadikan dollar AS sebagai salah satu investasi secara fisik yang dapat digunakan pada kondisi tersebut. Keadaan seperti ini yang menyebabkan Penurunan Indeks Harga Saham Gabungan pada tahun 2015 dimulai pada pertengan bulan Agustus 2015 di BEI.

\section{TINJAUAN PUSTAKA}

Indeks Harga Saham Gabungan atau Composite Stock Price Index (IHSG) 
Jurnal Ilmiah Ekonomi dan Bisnis

Vol. 15. No.1, Maret 2018: 50-56

EISSN : $2442-9813$

ISSN : $1829-9822$

merupakan suatu nilai yang digunakan untuk mengukur kinerja kerja saham yang tercatat di suatu bursa efek. Seperti di mayoritas busra-busra dunia, Indeks yang ada di BEI dihitung dengan menggunakan metodologi rata-rata tertimbang berdasarkan jumlah saham tercatat (nilai pasar) atau Market Value Weighted Average Index.

Menurut Kuncoro (2011) tingkat inflasi adalah kecenderungan dari harga untuk meningkat secara umum dan terus menerus. Kenaikan harga dari satu atau dua barang tidak dapat disebut Inflasi, kecuali bila kenaikan tersebut meluas atau mengakibatkan kenaikan kepada barang lainnya.Menurut Boediono (1998) definisi singkat dari Inflasi adalah kecenderungan dari harga-harga untuk menaik secara umum dan terus menerus. Kenaikan harga dari satu atau dua barang saja tidak disebut Inflasi. Syarat adanya kecenderungan menaik yang terus menerus juga perlu digaris-bawahi.

Menurut Putong (2002), Inflasi dibedakan atas tiga jenis, antara lain:Menurut Sifatnya, Inflasi jika dilihat dari penyebabnya dan Inflasi dibagi menjadi dua jika dilihat dari asalnya.

Menurut Wibowo dan Suhendra (2010) bahwa tingkat suku bunga digunakan pemerintah untuk mengendalikan tingkat harga, ketika tingkat harga tinggi dan jumlah uang yang beredar dalam masyarakat banyak sehingga konsumsi masyarakat tinggi akan diantisipasi oleh pemerintah dengan menetapkan tingkat suku bunga yang tinggi.

Tingkat suku bunga dapat didefinisikan sebagai tingkat pengembalian aset yang mempunyai risiko mendekati nol. Investor dapat menggunakan tingkat bunga sebagai patokan (benchmark) untuk perbandingan bila ingin berinvestasi.

Menurut Tandelilin (2010) bahwa tingkat sukumempengaruhi harga saham secara terbalik (Cateris Paribus). Bila pemerintah mengumumkan tingkat suku bunga yang lebih tinggi maka investor akan menjual sahamnya dan beralih berinvestasi pada sektor perbankan seperti deposito dan tabungan.

Kurs valuta asing atau kurs uang asing menujukkan harga atau nilai mata uang sesuatu negara dinyatakan dalam nilai mata uang negara lain. Kurs valuta asing dapat juga didefinisikan jumlah uang domestik yang dibutuhkan, yaitu banyaknya rupiah yang dibutuhkan untuk memper oleh satu unit mata uang asing. Pertukaran antara dua mata uang yang berbeda dimana akan terdapat perbandinagan nilai atau harga antara kedua mata uang tersebut. Perbandingan nilai inilah yang disebut kurs. Kurs valuta adalah harga satu unit valuta yang ditunjukkan dalam valuta lain. (Sukirno, 2010).

\section{METODE PENELITIAN}

Jenis penelitian yang ada dalam penelitian ini adalah penelitian kuantitatif. Jenis data yang digunakan peneliti dalam penelitian ini adalah data kuantitatif time seris ( runtut waktu) yang bersumber dari data sekunder, yaitu data yang diperoleh secara tidak langsung atau melalui informasi yang yang didapatkan dari buku, dokumen, maupun situs lembaga tertentu. Dalam penelitin ini data IHSG bersumber dari informasi http://.yahoofinance.com anuualy 20112015, dan data tingnkat inflasi, suku bunga dan nilai kurs yang bersumber dari Bank Indonesia www.bi.go.id. Jumlah data ada setiap bulan selama 5 tahun sehingga ada 60 data Tingkat Inflasi, Tingkat Suku, Nilai Kurs Dollar ASdan Indeks Harga Saham Gabungan.

Dalam pengumpulan data penulis menggunakan teknik dokumentasi dengan mengumpulkan data, bukti, dan keterangan.

Analisis regresi liner berganda bertujuan untuk membuktikan ada atau tidaknya hubungan fungsional antara tiga buah variabel bebas $\mathrm{X}$ (tingkat inflasi, 
suku bunga dan nilia kurs dollar AS)dari sebuah variabel terikat Y(IHSG). Dalam penelitian ini analisis tersebut digunakan untuk mengetahui. Seberapa besar variabel independen mempengaruhi variabel dependen dihitung dengan persamaan regresi berganda sebagai berikut :

$$
\begin{aligned}
& Y=a+b X 1+b X 2+b X 3+e . \\
& \text { Keterangan : } \\
& Y=\text { IHSG sektor pertambangan } \\
& \text { (a) = Nilai Konstanta } \\
& (b)=\text { Koefisien Regresi Berganda } \\
& (X 1)=\text { tingkat inflasi } \\
& (X 2)=\text { suku bnga } \\
& (X 3)=\text { nilai kurs dollar AS } \\
& (e)=\text { Standart Error. }
\end{aligned}
$$

\section{HASIL DAN PEMBAHASAN}

Dari tabel 7 diatas, dapat dituliskan persamaan sebagai berikut: $\mathrm{Y}=-243,9461-11,32092 \mathrm{X} 1-$ $24,62072 \mathrm{X} 2+0,217184 \mathrm{X} 3+\mathrm{e}$. Dimana nilai konstanta sebesar 24,39461. Nilai koefisien ini menunjukkan jika tidak ada perubahan pada variabel tingkat inflasi, suku bunga dan kurs rupiah maka IHSG akan mengalami penurunan sebesar 24,39461 poin.

Ini menunjukkan koefisien kolerasi Tingkat Inflasi (X1) sebesar 11,32092. Tanda negatif menunjukkan arah berlawanan atau berbanding terbalik. Jika variabel tingkat inflasi meningkat $1 \%$ maka IHSG akan mengalami penurunan sebesar 11,32092 poin, dan sebaliknya apabila tingkat inflasi menurun $1 \%$ maka IHSG akan mengalami peningkatan sebesar 11,32092 poin.

Koefisien kolerasi Suku Bunga (X2)sebesar -24,62072. Tanda negatif menunjukkan arah berlawanan atau berbanding terbalik. Jika variabel tingkat suku bunga meningkat $1 \%$ maka IHSG akan mengalami penurunan sebesar 24,62072 poin, dan sebaliknya apabila tingkat inflasi menurun $1 \%$ maka IHSG akan mengalami peningkatan sebesar 24,62072 poin.

Nilai F-statistic sebesar 14.58881 dengan nilai signifikan probability $F$ statistic adalah 0.000000 , tingkat probabilitasnya lebih kecil dari 0,05 atau $<0,05$. Hal tersebut mengidentifikasi bahwa semua variabel independen $(\mathrm{X} 1, \mathrm{X} 2$ dan X3) berpengaruh secara signifikan terhadap variabel dependen (IHSG).

Dari hasil pengolahan data dihasilkan tingkat inflasi menunjukkan $t_{\text {hitung }}-0,257149$ dengan nilai yang tidak signifikan 0,7980 lebih dari tingkat alpha0,05 dan koefisien $\beta$ sebesar 11,32092 menunjukkan nilai negatif. Hal ini berarti bahwa tingkat inflasi berpengaruh negatif dan tidak signifikan terhadap indeks harga saham gabungan (IHSG).

Suku bunga menunjukkan $t_{\text {hitung }}$ 0,230620 dengan nilai yang signifikan 0,0485 kecil dari alpha0,05 dan koefisien $\beta$ sebesar -24,62072 menunjukkan negatif. Hal ini berarti bahwa suku bunga berpengaruh negatif dan signifikan terhadap Indeks Harga Saham Gabungan (IHSG).

Sedangkan untuk nilai kurs menunjukkan $t_{\text {hitung }}$ 4,291064 dengan nilai yang signifikan 0,001 kecil dari alpha 0,05 dan koefisien $\beta$ sebesar 0,217184 menunjukkan positif. Hal ini berarti bahwa nilai kurs berpengaruh positif dan signifikan terhadap Indeks Harga Saham Gabungan (IHSG).

Dari hasil pengolahan data ditemukan nilai $R$-Square 0.408619 ini berarti bahwa variabel bebas X1 (Tingakt Inflasi),X2 (Suku Bunga) dan X3 (Nilai Kurs) mempengaruhi IHSG (Indeks Harga Saham Gabungan) sebesar 40,86\% sedangkan sisanya $59,14 \%$ dipengaruhi oleh faktor lain.

Dari hasil penelitian nilai koefisien regresi untuk variabel tingkat inflasi yang diproxy oleh (IHSG) sebesar -11,32092 bertanda negatif dengan nilai probability $0.7980>0,05$ yang berarti bahwa inflasi 
Jurnal Ilmiah Ekonomi dan Bisnis

Vol. 15. No.1, Maret 2018: 50-56

EISSN : $2442-9813$

ISSN : $1829-9822$

mempunyai pengaruh negatif dan tidak signifikan terhadap probabilitas yang diproxy oleh IHSG (Indeks Harga Saham Gabungan).Dengan demikian dapat disimpulkan hipotesis pertama ditolak.

Tidak signifikannya pengaruh inflasi pada penelitian ini dikarenakan selama periode pengamatan tingkat inflasi berada dalam katergori inflasi ringan berkisar pada $3,35 \%$ sampai $8,37 \%$ atau bisa dikatakan bahwa tingkat inflasi masih dibawah $10 \%$. Namun, bila inflasi menembus angka $10 \%$, maka pasar modal akan terganggu.

Hal ini menandakan bahwa tingkat inflasi tidak berpengaruh banyak terhadap keputusan investor dalam menanamkan modalnya pada periode pengamatan dikarenakan tidak adanya pengaruh yang signifikan antara tingkat inflasi dengan IHSG.

Penelitian ini mempunyai hasil yang sama dengan penelitian yang dilakukan oleh Kumalasari, dkk. (2016) melakukan penelitian tentang Pengaruh Nilai Tukar, Bi Rate, Tingkat Inflasi dan Pertumbuhan Ekonomi terhadap Indeks Harga Saham Gabungan dimana tingkat inflasi berpengaruh negatif dan tidak signifikan terhadap Indeks Harga Saham Gabungan (IHSG).

Penelitian ini juga didukung oleh penelitian yang dilakukan Kewal (2012) melakukan penelitian tentang Pengaruh Inflasi, Suku Bunga, Kurs dan Pertumbuhan PDB terhadap Indeks Harga Saham Gabungan yang menemukan bahwa Tingakt Inflasi berpengaruh negatif dan tidak signifikan terhadap IHSG.

Nilai koefisien regresi untuk variabel Suku Bunga yang diproxy oleh IHSG (Indeks Harga Saham Gabungan) sebesar -246,2072 bertanda negatif dengan nilai probability $0.0485<0,05$ yang berarti bahwa suku bunga mempunyai pengaruh negatif signifikan terhadap IHSG (Indeks Harga Saham
Gabungan). Dengan demikian dapat disimpulkan hipotesis kedua diterima.

Tanda negatif pada koefesien menunjukkan adanya pengaruh yang berlawanan. Apabila tingkat suku bunga naik, maka IHSG akan turun, dan sebaliknya apabila tingkat suku bunga turun maka IHSG akan naik. Pengaruh negatif yang diberikan variabel tingkat suku bunga terhadap IHSG sesuai dengan pendapat Tandelin (2010) yang menyebutkan bahwa suku bunga mempengaruhi harga saham secara terbalik (cateris paribus).

Apabila tingkat suku bunga naik maka return investasi dalam bentuk perbankan akan naik sehinggabanyak investor menjual sahamnya dan beralih padainvestasi pada sektor perbankan baik dalam bentuk tabungan maupun deposito. Hal ini menyebabkan penurunan pada harga saham dan IHSG.

Hasil penelitian ini sama dengan penelitian yang dilakukan oleh Maurina, dkk. (2015) yang berjudul Pengaruh Tingkat Inflasi, Kurs Rupiah dan Tingkat Suku Bunga Bi Rate terhadap IHSG menunjukkan terdapat pengaruh negatif dan signifikan antara tingkat suku bunga BI Rate terhadap IHSG.

Nilai koefisien regresi untuk variabel Nilai Kurs yang diproxy oleh IHSG (Indeks Harga Saham Gabungan) 0.217184 bertanda positif dengan nilai probability $0.0001<0,05$ yang berarti bahwa nilai kurs mempunyai pengaruh positif dan signifikan terhadap IHSG (Indeks Harga Saham Gabungan). Dengan demikian dapat disimpulkan hipotesis ketiga diterima.

Pengaruh positif yang diberikan variabel kurs rupiah terhadap IHSG menujukkan bahwa penguatan kurs US dollar (rupiah terdepresiasi) justru akan meningkatkan IHSG. Hal ini terjadi karena penurunan nilai tukar rupiah mengakibatkan makin murahnya produk ekspor asal Indonesia di pasar mancanegara. Hal ini akan menyeabkan 
meningkatnya permintaan akan produk ekspor indonesia. Hal ini dapat membuat pengeluaran agregat atas output dapat meningkat, persedian menurun, dan PDB riil akan meningkat. Maka dapat disimpulkan bahwa depresiasi mata uang suatu negara cenderung meningkatkan PDB negara tersebut dan kenaikan PDB ini dapat mendorong kenaikan investasi di dalam negeri, sehingga hal ini juga dapat mendorong kenaikan IHSG.

Kenaikan tingkat kurs juga dapat mendorong kenaikan tingkat harga. Menurut Case dan Fair (2007) kenaikan mata uang suatu negara cenderung meningkatkan tingkat harganya. Ada dua alasan efek ini terjadi. Pertama, ketika mata uang suatu negara lebih murah, produknya lebih kompetitif di pasar dunia, sehingga ekspor naik. Di samping itu, pembeli domestik cenderung mensubtitusi barang (impor yang lebih) dengan produk domestik. Oleh karena itu, pengeluaran agregat yang direncanakan pada barang dan jasa buatan dalam negeri naik. Hasilnya adalah tingkat harga yang lebih tinggi, output yang lebih tinggi, atau keduanya. Kedua, depresiasi membuat input yang diimpor lebih mahal.

Hasil penelitian ini sama dengan penelitian yang dilakukan oleh Palatte dan Akbar yang berjudul Pengaruh Nilai Tukar Mata Uang Dan Tingkat Suku Bunga Terhadap Perkembangan Indeks Harga Saham Gabungan Di Bursa Efek Indonesia Periode 2009-2013 menunjukkan terdapat pengaruh positif dan signifikan terhadap Indeks Harga Saham Gabungan.

\section{KESIMPULAN DAN SARAN}

Hasil uji F (simultan) menunjukkan bahwa semua variabel independen berpengaruh secara signifikan terhadap variabel dependen (IHSG). Hasil uji t (parsial) menunjukkan bahwa hanya nilai tukar dan suku bunga yang berpengaruh signifikan terhadap
IHSG,dimana nilai tukar berpengaruh positif dan suku bunga berpengaruh negatif, sedangkan inflasi tidak signifikan terhadap IHSG. Koefisien determinasi dalam penelitian ini adalah sebesar 40,86\% sedangkan sisanya $100 \%-40,86 \%=$ $59,14 \%$ dipengaruhi oleh faktor lain.

Tingkat inflasiberpengaruh negatif dan tidak signifikan Indeks Harga Saham Gabungan (IHSG). Tingkat suku bunga berpengaruh negatif dan signifikan terhadap indeks harga saham gabungan. Nilai kurs berpengaruh positif dan signifikan terhadap IHSG (Indeks Harga Saham Gabungan).

Bagi akademis diharapkan hasil penelitian ini dapat menambah pengembangan ilmu pengetahuan, dapat membantu mahasiswa untuk menambah wawasan yang baru bahwa faktor-faktor ekonomi makro juga berpotensi mempengaruhi kinerja IHSG, jadi tidak hanya faktor-faktor internal bursa itu sendiri saja.

Berdasarkan hasil penelitian menyebutkan bahwa terdapat pengaruh antara tingkat inflasi, suku bunga dan nilai kurs terhadap IHSG, sehingga penting bagi para investor sebelum menentukan keputusan untuk berinvestasi agar lebih memperhatikan dan menganalisis perkembangan keadaan ekonomi makro sebagai salah satu upaya memprediksi IHSG di pasar modal.

Bagi Peneliti selanjutnya. Untuk penelitian dengan topik yang sama terutama mengenai IHSG, sebaiknya peneliti berikutnya menambahkan jumlah tahun sampel mulai tahun 1997 awal mulai krisis ekonomi di indonesia dan krisis finansial global sehingga akan diketahui konsistensi variabel tersebut dalam melihat pengaruh faktor-faktor yang mempengaruhi Indeks Harga Saham Gabungan (IHSG). Untuk penelitian selanjutnya sebaiknya menambahkan beberapa variabel yang belum disebutkan dalam penelitian ini. Berdasarkan uji koefisien determeniasi menyebutkan bahwa terdapat $51,13 \%$ varians variabel IHSG yang dapat 
Jurnal Ilmiah Ekonomi dan Bísnís

Vol. 15. No.1, Maret 2018: 50-56

EISSN : $2442-9813$

dijelaskan oleh variabel independen diluar model regresi.

\section{DAFTAR PUSTAKA}

Ang, Robbert.1997, “ Pasar Modal Indonesia”. Mediasoft Jakarta.

Case dan Fair. 2007. "Prinsip-Prinsip Ekonomi”. Edisi 8 Jilid 2. Jakarta: Erlangga. Lembaga Penerbit Fakultas Ekonomi Universitas Indonesia

Hartono, jogiyanto. 2013 "Teori Portofolio Dan Analisis Investasi”. Edisi kedelapan. Yogyakarta: BPEE

Ghozali, Imam. 2005. Aplikasi Analisis Multivariate Dengan Program SPSS. Semarang: Badan Penerbit Universitas Diponegor.

Gujarati, Damodar. 2003. Ekonometrika Dasar. Erlangga: Jakarta.

Kewal, Suramaya suci. 2012."Pengaruh Inflasi, Suku Bunga, Dan Pertumbuhan PDB Terhadap Indeks Harga Saham Gabungan”. Jurnal ekonomi. Volume 8. Nomor 1. April 2012

Kuncoro, mudrajad. 2001. Metode Kuantitatif Teori Dan Aplikasi Untuk Bisnis Dan Ekonomi. Edisi 1, Cetakan 1 Unit Penerbitan Dan Percetakan AMP YKPN, Yogyakarta.

Maurina. Yenita, R. Rustam Hidayat, Sri Sulasmiyati. 2015. "Pengaruh Tingkat Inflasi, Kurs Rupiah Dan Tingkat Suku Bunga BI Rate Tetrhadap IHSG (Studi Pada Bursa Efek Indonesia Periode 2010-2014)’. Jurnal administrasi bisnis (JAB). $\quad$ Vol. $27 \quad$ No.2 Oktober 2015.

Palatte, Muh.Halim dan Akbar. 2014. "Pengaruh Nilai Tukarmata Uang Dan Tingkat Suku Bunga Terhadap Perkembangan Indeks Harga Saham Gabungan Di Bursa Efek Indonesia Periode 20092013”. Jurnal Manajemen. Vol. 01 No.02. Juli 2014

Putong, Iskandar. 2002.” Ekonomi mikro \& makro". Edisi 2. Ghalia Indonesia

Sukirno, Sadono. 2010. Makro Ekonomi Teori Pengantar. Edisi Ketiga. Jakarta: Kelapa Gading.

Tandelin, Eduardus. 2010 "Potofolio Dan Investasi Teori Dan Aplikasi".Edisi pertama.Penerbit KANISIUS Yogyakarta.

http://www.finance.yahoo.com

www.bi.go.id

www.bps.go. 